\title{
Phosphoketolase in Rhodotorula graminis and Other Yeasts
}

\author{
By DEREK A. WHITWORTH* AND COLIN RATLEDGE \\ Department of Biochemistry, University of Hull, Hull HU6 ${ }_{7} R X$
}

(Received 4 May 1977)

\begin{abstract}
Phosphoketolase(s), catalysing the cleavage of xylulose 5-phosphate and fructose 6-phosphate, were found in Rhodotorula graminis, $R$. glutinis, Candida 107 and $C$. tropicalis. Activity towards the latter substrate only was found in $C$. humicola. Neither activity was found in Saccharomyces carlsbergensis. The enzyme(s) were isolated and purified eightfold from $R$. graminis. Inorganic phosphate, thiamin pyrophosphate and $\mathrm{Mg}^{2+}$ were required for activity. The enzyme had a $K_{\mathrm{m}}$ of $\mathrm{I} \cdot 25 \mathrm{mM}$ for xylulose 5-phosphate and was markedly sensitive to NADH, NADPH, ATP and acetyl-CoA and less sensitive to phosphoenolpyruvate, citrate and dodecanoyl-CoA. The activity of phosphoketolase was halved in the presence of an active transketolase which competes with it for the same substrate. The contribution of phosphoketolase to glucose catabolism may be only slight.
\end{abstract}

\section{INTRODUCTION}

The apparent absence of phosphofructokinase in species of Rhodotorula (Brady \& Chambliss, 1967; Höfer, 1968) led to a proposal that phosphoketolase, catalysing

$$
\text { xylulose 5-phosphate } \longrightarrow \text { glyceraldehyde 3-phosphate }+\mathrm{C}_{2} \text { unit }
$$

or $\quad$ fructose 6-phosphate $\longrightarrow$ erythrose 4-phosphate $+C_{2}$ unit

was present as an adjunct to the pentose cycle (Höfer et al., 1969, I97I; Höfer, Betz \& Becker, 1970). Such a proposal was needed as the pentose cycle produces only one $C_{2}$ unit from each molecule of glucose. The presence of phosphoketolase was never verified, though glyoxylate reductase, catalysing

$$
\text { glycollate }+\mathrm{NAD}^{+} \longrightarrow \text { glyoxylate }+\mathrm{NADH}
$$

was found (Höfer et al., 1970), and this was said to confirm the existence of phosphoketolase and also that the $C_{2}$ product of its reaction was glycollate. However, the nature of the $C_{2}$ units is probably 2 - $(\alpha, \beta$-dihydroxyethyl)thiamin pyrophosphate (enzyme-bound) which can break down to a number of products including glycollate or acetyl phosphate depending on the assay conditions (Horecker, 1962; Goldberg \& Racker, 1962; Schröter \& Holzer, 1963).

As at this stage we had also failed to find phosphofructokinase in several oleaginous yeasts including Rhodotorula spp. and Candida 107 (Whitworth \& Ratledge, I975a, b), we subsequently searched for, and found, phosphoketolase in these yeasts. We now present some of the properties of this enzyme which has hitherto only been recognized in the heterofermentative lactobacilli and the bifidobacteria (Doelle, I969; Sgorbati, Lenaz \& Casalicchio, 1976).

The enzyme, however, probably does not have the metabolic importance previously

* Present address: Forest Products Division, Forest Research Institute, New Zealand Forest Service, Rotorua, New Zealand. 
attached to it as the conventional glycolytic pathway has now been established in $R$. glutinis, $R$. graminis and Candida 107 by the finding of phosphofructokinase (Mazón, Gancedo \& Gancedo, 1974; Ratledge \& Botham, 1977).

\section{METHODS}

Growth of yeasts and preparation of cell-free extracts. Candida 107 Ruinen \& Deinema 1964, Candida humicola $\mathrm{NCYC}_{4} 6 \mathrm{I}$, Candida tropicalis $\mathrm{NCYC}^{2}$, Rhodotorula graminis NCYC502, Rhodotorula glutinis (syn. gracilis) NCYC59 and Saccharomyces carlsbergensis $\mathrm{NCYC}_{30}$ were grown on a glucose/salts medium at $\mathrm{pH} 5.5$ as described by Ratledge \& Botham (1977). The yeasts, usually grown in $100 \mathrm{ml}$ medium in $250 \mathrm{ml}$ conical flasks for $48 \mathrm{~h}$, were harvested, washed and disrupted as previously described (Whitworth \& Ratledge, 1975a). Extracts were centrifuged at $45000 \mathrm{~g}$ for $30 \mathrm{~min}$ and the supernatant fluids were used in assays. Protein was measured by the biuret method (Gornall, Bardawill \& David, 1949).

\section{Enzyme assays}

Phosphoketolase(s) [EC 4.1.2.9; D-xylulose-5-phosphate D-glyceraldehyde-3-phosphate-lyase (phosphate-acetylating), and EC 4.I.2.22; D-fructose-6-phosphate D-erythrose-4-phosphate-lyase (phosphateacetylating)]. Two discontinuous methods were used, the first being suitable for assaying hexose phosphoketolase, the second for pentose phosphoketolase. Unless stated otherwise all results refer to the enzyme assayed by the latter procedure.

(i) Assay of acetyl phosphate as ferric acetyl hydroxamate (based on the method of Racker, 1962; and method B of Goldberg, Fessenden \& Racker, 1966). The reaction mixture contained, in I ml: cell extract, about O.I ml; histidine/ $\mathrm{HCl}$ buffer, $\mathrm{pH} 6.0,50 \mathrm{mM} ; \mathrm{KH}_{2} \mathrm{PO}_{4} / \mathrm{KOH}$ buffer, $\mathrm{pH} \mathrm{6.0,20} \mathrm{mM:} \mathrm{MgCl}_{2}$, I mM; dithiothreitol, $2 \mathrm{~mm}$; thiamin pyrophosphate (TPP), $0.3 \mathrm{~mm}$; and, to initiate the reaction, fructose 6-phosphate, $20 \mathrm{~mm}$. After incubating at $30^{\circ} \mathrm{C}$ for $15 \mathrm{~min}, 0.5 \mathrm{ml} 2 \mathrm{M}$-hydroxylamine hydrochloride, $\mathrm{pH} 5.4$, was added and, 10 min later, $\mathrm{I} .5 \mathrm{ml} 20 \%(\mathrm{w} / \mathrm{v}) \mathrm{FeCl}_{3}$ in $0 . \mathrm{I} \mathrm{M}-\mathrm{HCl}$. After centrifuging, $E_{540}$ was measured immediately to give the amount of acetyl phosphate formed.

(ii) Assay of glyceraldehyde 3-phosphate by its enzymic conversion to fructose I,6-bisphosphate (Goldberg et al., 1966; method A). The reaction mixture contained, in $150 \mu \mathrm{l}$ : cell extract, about $25 \mu \mathrm{l} ; \mathrm{KH}_{2} \mathrm{PO}_{\mathrm{J}} / \mathrm{KOH}$ buffer, pH 6.0, $33 \mathrm{~mm}$; dithiothreitol, $3.3 \mathrm{~mm}$; $\mathrm{MgCl}_{2}, 3.3 \mathrm{~mm}$; TPP, $0.7 \mathrm{~mm}$; $\alpha$-glycerophosphate dehydrogenase, 0.2 unit; triosephosphate isomerase, $\mathrm{I} \cdot 6$ units; aldolase, 0.1 unit; and, to initiate the reaction, xylulose 5-phosphate, $1.7 \mathrm{~mm}$. After $5 \mathrm{~min}$ at $30^{\circ} \mathrm{C}$, the tubes were held in boiling water for $\mathrm{I} \mathrm{min}$. When cool, the precipitate was removed by centrifuging and the amount of fructose 1,6-bisphosphate formed from the glyceraldehyde 3-phosphate was measured in $50 \mu \mathrm{l}$ of the supernatant solution by adding it to $50 \mathrm{~mm}$-triethanolamine/ $\mathrm{HCl}$ buffer, $\mathrm{pH} 7 \cdot 5$, plus glyceraldehyde-3-phosphate isomerase, $\alpha$-glycerophosphate dehydrogenase and aldolase (O.I unit of each) and $0.1 \mathrm{~mm}-\mathrm{NADH}$, all in a final volume of $\mathrm{I} \mathrm{ml}$. Measurement of $\Delta E_{310}$ gave the amount of glyceraldehyde 3-phosphate formed over the initial incubation period. As a control, the assay was conducted in the absence of xylulose 5-phosphate.

Acetate kinase [EC 2.7.2.1 ; ATP: acetate phosphotransferase] was assayed in the forward direction by the method of Rose (1955) and in the reverse direction in a similar assay system but using $15 \mathrm{~mm}$-acetyl phosphate as substrate. Both assays were discontinuous and the amount of acetyl phosphate present was determined after $30 \mathrm{~min}$ incubation.

Transketolase [EC 2.2.1.1; sedoheptulose-7-phosphate:D-glyceraldehyde-3-phosphate glycolaldehydetransferase] was assayed by the method of Kiely, Tan \& Wood (I969) by coupling with $\alpha$-glyceraldehyde dehydrogenase/triosephosphate isomerase and following oxidation of NADH at $340 \mathrm{~nm}$.

Purification of phosphoketolase. Rhodotorula graminis was cultured in 11 medium in a 21 conical flask with continuous shaking for 4 days. The cell-free extract was prepared as above and centrifuged at $100000 \mathrm{~g}$ for $\mathrm{I} h$. To the supernatant solution, streptomycin sulphate was added at $1.5 \mathrm{mg}$ ( $\mathrm{mg}$ protein) ${ }^{-1}$. After removing precipitated material, the supernatant was fractionated with ammonium sulphate. The 50 to $60 \%$ saturated fraction was dialysed against $50 \mathrm{~mm}$-phosphate buffer, $\mathrm{pH} \mathrm{7.5}$, and then applied to a column $(10 \times 30 \mathrm{~mm})$ of hydroxylapatite which was eluted with a gradient of phosphate buffer from 50 to $250 \mathrm{mM}$. Active fractions were combined and used in further experiments.

Biochemicals were obtained from Sigma.

\section{RESULTS AND DISCUSSION}

Of the various supernatant solutions of disrupted yeasts which were examined for phosphoketolase activity (Table I), the most promising source for further study appeared 
Table 1. Activity of phosphoketolase in extracts from various yeasts

Phosphoketolase activity was assayed with the coupled enzyme assay method with xylulose 5-phosphate (Xu 5-P) as substrate. With fructose 6-phosphate (F 6-P) as substrate, the acetyl hydroxamate method was used which consistently gave no activity when the substrate was omitted. Activities are expressed as nmol substrate converted $\min ^{-1}$ ( $\mathrm{mg}$ protein) ${ }^{-1}$.

\begin{tabular}{|c|c|c|c|}
\hline \multirow[b]{2}{*}{ Yeast } & \multicolumn{2}{|c|}{ Xu 5-P substrate } & \multirow{2}{*}{$\begin{array}{l}\text { F 6-P substrate } \\
\begin{array}{c}\text { Complete } \\
\text { assay }\end{array}\end{array}$} \\
\hline & $\begin{array}{l}\text { Complete } \\
\text { assay }\end{array}$ & $\begin{array}{l}\text { Assay - } \\
\text { substrate }\end{array}$ & \\
\hline $\begin{array}{l}\text { S. carlsbergensis } \\
\text { C. humicola }\end{array}$ & $\begin{array}{r}4 \cdot 7 \\
18 \cdot 9\end{array}$ & $\begin{array}{r}7 \cdot 0 \\
20 \cdot 8\end{array}$ & $\begin{array}{r}0.5 \\
10.0\end{array}$ \\
\hline Candida 107 & $3 \cdot 1$ & 0 & $1 \cdot 7$ \\
\hline C. tropicalis & $8 \cdot 3$ & $2 \cdot 5$ & $I \cdot 4$ \\
\hline R. graminis & $4 \cdot 4$ & $1 \cdot 5$ & $8 \cdot 7$ \\
\hline R. glutinis & $5 \cdot 1$ & $1 \cdot 0$ & $1 \cdot 9$ \\
\hline
\end{tabular}

to be that from $R$. graminis. The enzyme was not detected in $S$. carlsbergensis. Candida humicola gave a high specific activity only when fructose 6-phosphate was the substrate.

Since the assays with fructose 6-phosphate as substrate were conducted with crude extracts, enzymes producing or degrading acetyl phosphate might have interfered. Acetate kinase was assayed in both directions but the level of its activity was very much less than that due to phosphoketolase. Extracts were also assayed for glyoxylate reductase activity (see Höfer et al., 1969) in both directions by the method of Zelitch \& Gotto (1962) but no significant levels were found.

\section{Purification and properties of phosphoketolase from $R$. graminis}

Phosphoketolase from $R$. graminis was purified twofold after ammonium sulphate precipitation and a further fourfold by chromatography through hydroxylapatite with an overall recovery of activity of $12 \%$. (Phosphoketolase from Candida 107 was not successfully purified using this procedure.) Neither calcium phosphate gel, alumina $\mathrm{C}_{\gamma}$ nor Sephadex G-I 50 was suitable as a final purification step. Fractions eluted from the hydroxylapatite column, which showed a peak of activity with fructose 6-phosphate as substrate, preceded those showing optimum activity with xylulose 5-phosphate. Therefore, although different assay procedures were used with each substrate, hexose and pentose phosphoketolase activities might not belong to the same enzyme.

The purified preparation lost $50 \%$ of its activity in $24 \mathrm{~h}$ at $4{ }^{\circ} \mathrm{C}$. Inorganic phosphate was essential to maintain stability; when phosphate buffer was replaced by equimolar Tris/maleate buffer at the same $\mathrm{pH}$, complete loss of activity occurred within $30 \mathrm{~min}$. TPP was also essential for activity. Activity diminished upon dialysis but could be restored by adding $\mathrm{Mg}^{2+}$. The enzyme exhibited its maximum activity at $\mathrm{pH} 6.0$; at $\mathrm{pH} 5.5$ and $\mathrm{pH} 7.0$ the activity was less than $40 \%$ of the maximum. The optimum temperature for the assay was $30{ }^{\circ} \mathrm{C}$; at $27.5{ }^{\circ} \mathrm{C}$ the activity was $70 \%$ of the maximum and at $32.5{ }^{\circ} \mathrm{C}$ was $30 \%$. Under the optimum conditions of assay, the enzyme had a $K_{\mathrm{m}}$ of $1 \cdot 25 \mathrm{~mm}$ for xylulose 5-phosphate calculated from a double reciprocal plot in the usual manner.

The enzyme was inhibited by NADH, NADPH, phosphoenolpyruvate, citrate, ATP, acetyl-CoA and dodecanoyl-CoA (Table 2). None of these metabolites affected the activity of the coupling enzyme, i.e. if added after the reaction was stopped. (NADH and NADPH, though they could not be checked in this way as the second part of the assay requires $\mathrm{NAD}(\mathrm{P}) \mathrm{H}$ to be added at $\mathrm{O} \cdot \mathrm{I} \mathrm{mM}$, would clearly not interfere with the assay procedure.) The enzyme was particularly sensitive to NADH, NADPH, ATP and acetyl-CoA. The inhibition by reduced nicotinamide coenzymes was not relieved by adding higher concentrations of the oxidized coenzymes. 
Table 2. Effect of various metabolites on phosphoketolase activity

Phosphoketolase activity was assayed by estimation of glyceraldehyde 3-phosphate using xylulose 5-phosphate as substrate; activities are expressed as nmol $\min ^{-1}$ (mg protein) ${ }^{-1}$. Neither citrate, phosphoenolpyruvate, ATP (at $2 \mathrm{~mm}$ ) nor acetyl-CoA (at $0.2 \mathrm{mM}$ ) affected the estimation of glyceraldehyde 3-phosphate. NADH and NADPH could not be so tested as NAD(P)H (at 0.I mM) is already added to the coupled enzyme assay system.

$\begin{array}{lcc}\text { Effector } & \begin{array}{c}\text { Concn } \\ \text { (mM) }\end{array} & \begin{array}{c}\text { Phosphoketolase } \\ \text { activity }\end{array} \\ \text { None } & & 108 \\ \text { NADH } & 0.2 & 0 \\ & 0.05 & 22 \\ \text { NADH+NAD } & 0.1+0.5 & 22 \\ \text { NADPH } & 0.2 & 0 \\ & 0.05 & 38 \\ \text { NADPH+NADP } & 0.1+0.5 & 5 \\ \text { Phosphoenolpyruvate } & 10 & 27 \\ & 2 & 60 \\ \text { Citrate } & 10 & 27 \\ & 2 & 40 \\ \text { ATP } & 0.1 & 0 \\ & 0.01 & 51 \\ \text { Acetyl-CoA } & 0.1 & 0 \\ & 0.05 & 27 \\ \text { Dodecanoyl-CoA } & 0.5 & 11\end{array}$

\section{Phosphoketolase and transketolase activities}

Transketolase converts xylulose 5-phosphate with either ribose 5-phosphate or erythrose 4-phosphate into glyceraldehyde 3-phosphate and either sedoheptulose 7-phosphate or fructose 6-phosphate. Its assay is similar to that for phosphoketolase as it uses the same substrate and relies on the formation and subsequent enzymic dehydrogenation of glyceraldehyde 3-phosphate. When enzyme preparations were assayed for transketolase, full activity $\left[485 \mathrm{nmol}\right.$ product formed $\mathrm{min}^{-1}(\mathrm{mg} \text { protein })^{-1}$ ] was found with xylulose 5phosphate and ribose 5-phosphate together. Without the former substrate the activity dropped by $67 \%$ and without the latter no activity occurred. When the phosphoketolase assay was carried out by following the formation of acetyl phosphate (i.e. in the assay usually used with fructose 6-phosphate as substrate) with both xylulose 5-phosphate and ribose 5-phosphate present, its activity was halved due to the competition of transketolase for the substrate. Thus, both the pentose phosphate cycle and the phosphoketolase pathway compete for the same substrate, xylulose 5-phosphate.

The contribution which phosphoketolase makes to glucose catabolism may be only slight. Its low activity, sensitivity to intracellular metabolites and its competition with transketolase for its substrate are not the hallmarks of a major controlling enzyme. Why phosphoketolase should be present at all is a puzzle. As its purpose is to divert carbon from the pentose cycle into the tricarboxylic acid cycle it could only play a major role if the Embden-Meyerhof pathway was absent or functioning at a low level and this possibility has been eliminated by the recent discoveries of phosphofructokinase in $R$. glutinis, $R$. graminis and Candida 107 (Mazón et al., 1974; Ratledge \& Botham, I977). Perhaps as we understand more of the control and regulation of glucose metabolism in these yeasts the significance of phosphoketolase will become apparent. Speculation at this stage is therefore unwarranted.

This work was supported by a grant (B/RG/5391.9) from the Science Research Council. We thank Mrs Susan Freeman for her technical assistance. 


\section{REFERENCES}

Brady, R. J. \& Chambliss, G. H. (1967). The lack of phosphofructokinase activity in several species of Rhodotorula. Biochemical and Biophysical Research Communications 29, 898-903.

Doelle, H. W. (1969). Bacterial Metabolism, pp. 171-175. New York and London: Academic Press.

Goldberg, M. L. \& Racker, E. (I962). Formation and isolation of a glycolaldehyde-phosphoketolase interrnediate. Journal of Biological Chemistry 237, $384 I^{-}-3842$.

GoldberG, M., Fessenden, J. M. \& Racker, E. (1966). Phosphoketolase. Methods in Enzymology 9, 515-520.

Gornall A. G., Bardawill, C. J. \& David, M. M (1949). Determination of serum proteins by means of the biuret reaction. Journal of Biological Chemistry 177, 75I-766.

HöFER, M. (I 968). Estimation of pathways of glucose catabolism in Rhodotorula gracilis. Folia microbiologica (Praha) 13, 373-377.

Höfer, M. Becker, J.-U., Brand, K., DeCkner, H. \& BeTz, A. (1969). A study of the enzyme equipment of the yeast Rhodotorula gracilis. FEBS Letters 3, 322-324.

HÖFER, M., BeTZ, A. \& BeCKer, J.-U. (I970). Metabolism of the obligatory aerobic yeast Rhodotorula gracilis. I. Changes in metabolite concentrations following D-glucose and D-xylose addition to the cell suspension. Archiv für Mikrobiologie 71, 99-110.

Höfer, M., Brand, K., Deckner, H. \& Becker, J.-U. (197I). Importance of the pentose phosphate pathway for D-glucose catabolism in the obligatory aerobic yeast Rhodotorula gracilis. Biochemical Journal 123, 855-863.

HORECKER, B. L. (1962). D-Xylulose-5-phosphate phosphoketolase. Methods in Enzymology 5, 261-266.

Kiely, M. E., TAN, E. L. \& Wood, T. (1969). The purification of transketolase from Candida utilis. Canadian Journal of Biochemistry 47, 455-460.
Mazón, M. J., Gancedo, J. M. \& Gancedo, C. (1974). Identification of an unusual phosphofructokinase in the red yeast Rhodotorula glutinis. Biochemical and Biophysical Research Communications 6r, $1304-1309$.

RACKER, E. (1962). Fructose-6-phosphate phosphoketolase from Acetobacter xylinum. Methods in Enzymology 5, 276-280.

Ratledge, C. \& Botham, P. A. (1977). Pathways of glucose metabolism in Candida 107, a lipidaccumulating yeast. Journal of General Microbiology 102, $391-395$.

Rose, I. A. (1955). Acetate kinase of bacteria (acetokinase). Methods in Enzymology 1, 591-595.

Ruinen, J. \& Deinema, M. H. (1964). Composition and properties of the extracellular lipids of yeast species from the phyllosphere. Antonie van Leeuwenhoek 30, 377-384.

SCHRÖTER, W.\& Holzer, H. (1963). Zum Wirkungsmechanisms der Phosphoketolase. II. Umsatz von -Thiaminpyrophosphat aktiviertem Glycolaldehyd'. Biochimica et biophysica acta 77, 474$48 \mathrm{I}$.

Sgorbati, B., lenaz, G. \& Casalicchio, F. (1976). Purification and properties of two fructose-6phosphate phosphoketolases in Bifidobacterium. Antonie van Leeuwenhoek 42, 49-57.

Whitworth, D. A. \& Ratledge, C. (1975a). An analysis of intermediary metabolism and its control in a fat synthesizing yeast (Candida 107) growing on glucose or alkanes. Journal of General Microbiology 88, 275-288.

Whitworth, D. A. \& RATledge, C. (1975b). Activities of regulatory enzymes in alkaneutilizing and lipid-accumulating yeasts and moulds. Journal of General Microbiology 90, I83-I 86.

Zelitch, I. \& Gotro, A. M. (I962). Properties of a new glyoxylate reductase from leaves. Biochemical Journal 84, 541-546. 